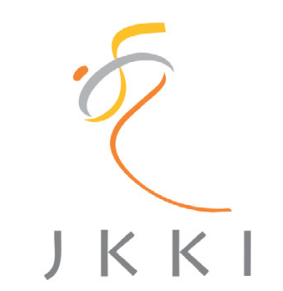

SCIEMTIA EST BASIC VITAE

\section{Jurnal Kedokteran dan Kesehatan Indonesia}

Indonesian Journal of Medicine and Health

Journal homepage : www.journal.uii.ac.id/index.php/JKKI

\title{
Effects of co-chemotherapy ethyl acetate fraction of Eurycoma longifolia jack roots and doxorubicin against apoptosis through expression p53 mutant and Bcl-2
}

\author{
Galih Dwi Mulyati*1, Laela Hayu Nurani², Sitarina Widyarini ${ }^{3}$ \\ ${ }^{1,2}$ Faculty of Pharmacy, University of Ahmad Dahlan, Yogyakarta \\ ${ }^{3}$ Faculty of Veterinary Medicine, University of Gadjah Mada, Yogyakarta
}

Original Article

\begin{tabular}{|c|c|}
\hline & ABSTRACT \\
\hline ARTICLE INFO & Background: It was found mutations of p53 gene in Breast cancer. Mutant \\
\hline $\begin{array}{l}\text { Keywords: } \\
\text { Eurycoma longifolia } \\
\text { Jack root mutant p53 } \\
\text { Bcl-2 co-chemotherapy } \\
\text { apoptosis }\end{array}$ & $\begin{array}{l}\text { increased expression of Bcl-2. Breast cancer therapy is commonly used } \\
\text { chemotherapy using Doxorubicin. However, effectiveness of the use of this } \\
\text { chemotherapeutic agent is limited due to the emergence of side effects } \\
\text { and toxic to normal cells. Therefore, it is necessary to develop new drugs } \\
\text { for combination of chemotherapy. Eurycoma longifolia Jack roots has the }\end{array}$ \\
\hline $\begin{array}{l}\text { *Corresponding author: } \\
\text { Galih.Dwi.GD@gmail.com }\end{array}$ & $\begin{array}{l}\text { potential as co-chemotherapy of breast cancer and it is not toxic to normal } \\
\text { cells. }\end{array}$ \\
\hline DOI : 10.20885/JKKI.Vol8.Iss1.art9 & Method: Rats were divided into 5 groups. Each group consisted of four \\
\hline $\begin{array}{l}\text { History: } \\
\text { Received : May 27, } 2016 \\
\text { Accepted : April 12, } 2017 \\
\text { Online } \quad \text { :April 26, } 2017\end{array}$ & $\begin{array}{l}\text { temale white Sprague Dawley rats. Group } 1 \text { (Normal), group } 2 \text { (DMBA } \\
20 \mathrm{mg} / \mathrm{kgB} . \mathrm{W}) \text {, group } 3 \text { (DMBA +Doxorubicin } 1.12 \mathrm{mg} / \mathrm{kgB} . \mathrm{W}) \text {, group } \\
4 \text { (DMBA +fractions } 100 \mathrm{mg} / \mathrm{kgB} . \mathrm{W}) \text {, group } 5 \text { (DMBA+Doxorubicin } \\
\text { +fractions). All the rats were sacrificed at weeks } 16 \text { and to be taken their } \\
\text { breast tissue. Immunohistochemistry was performed using a mouse } \\
\text { monoclonal antibody mutant (BioGenex) and Bcl-2 (BIOSS). } \\
\text { Results: expression of mutant p53 percentage obtained for group I ( } 9.35 \\
\pm 0.32) \% \text {, II }(21.65 \pm 1.60) \% \text {, III }(10.72 \pm 2.52) \% \text {, IV }(11.63 \pm 3.39) \%, \mathrm{~V} \\
(12.72 \pm 3.44) \% \text {, While the percentage of Bcl-2 expression obtained for } \\
\text { I }(20.62 \pm 10.09) \% \text {, II }(52.83 \pm 3.61) \% \text {, III }(24.38 \pm 3.54) \% \text {, IV }(38.01 \pm \\
6.25) \%, \mathrm{~V}(27.99 \pm 4.27) \% \text {. The data was statistically tested by Kruskal } \\
\text { Wallis test (p<0.005). } \\
\text { Conclussion: Co-chemotherapy of } E \text {. longifolia Jack roots and Doxorubicin } \\
\text { can stimulate apoptosis through decreased in the expression of mutant } \\
\text { p53 protein and Bcl-2 in breast tissue of rats induced by DMBA. }\end{array}$ \\
\hline
\end{tabular}

Latar Belakang: Mutasi pada gen p53 dapat dijumpai pada kanker payudara. Protein p53 mutan menyebabkan penurunan mekanisme apoptosis sel melalui peningkatan ekspresi Bcl-2. Terapi kanker payudara yang umum digunakan adalah kemoterapi dengan menggunakan Doxorubicin. Efektivitas penggunaan agen kemoterapi ini menjadi terbatas karena munculnya efek samping dan toksik pada sel normal. Oleh karena itu, perlu dikembangkan obat baru untuk kombinasi kemoterapi. Eurycoma longifolia Jack roots (akar pasak bumi) mempunyai potensi sebagai ko-kemoterapi kanker payudara dan tidak toksik pada sel normal.

Tujuan: Penelitian ini bertujuan untuk mengetahui efek ko-kemoterapi fraksi etil asetat Eurycoma longifolia Jack roots dan Doxorubicin terhadap apoptosis melalui ekspresi p53 mutan dan Bcl-2.

Metode: Tikus dibagi menjadi 5 kelompok. Masing-masing kelompok terdiri dari 4 ekor tikus putih betina Sprague dawley. Kelompok 1 (Normal), kelompok 2 diberikan DMBA (20 mg/kgBB), kelompok 3 
(DMBA +Doxorubicin 1,12 mg/kgBB), kelompok 4 (DMBA+Fraksi $100 \mathrm{mg} / \mathrm{kgBB})$, kelompok 5 (DMBA +Doxorubicin+Fraksi). Semua tikus dikorbankan pada minggu 16 dan diambil jaringan payudaranya. Imunohistokimia dilakukan dengan menggunakan mouse monoclonal antibody p53 mutan (Biogenex) dan Bcl-2 (Bioss).

Hasil: Persentase ekspresi p53 mutan yang diperoleh pada kelompok I (9,35 $\pm 0,32) \%$, II (21,65 $\pm 1,60) \%$, III $(10,72 \pm 2,52) \%$, IV $(11,63 \pm 3,39) \%$, dan $V(12,72 \pm 3,44) \%$. Persentase ekspresi Bcl-2 I $(20,62 \pm 10,09) \%$, II $(52,83 \pm 3,61) \%$, III $(24,38 \pm$ $3,54) \%$, IV $(38,01 \pm 6,25) \%$, dan $V(27,99 \pm 4,27) \%$. Data diuji statistika dengan menggunakan uji Kruskal Wallis $(p<0,005)$.

Kesimpulan: Ko-kemoterapi fraksi etil Eurycoma longifolia Jack roots dan Doxorubicin dapat memacu apoptosis melalui penurunan ekspresi protein p53 mutan dan Bcl-2 pada jaringan payudara tikus yang di induksi DMBA.

\section{INTRODUCTION}

Mutations of p53 gene (Tumor Suppressor Gene) is common in the variety of malignancies, one of it is in breast cancer. ${ }^{1}$ Loss of $p 53$ function due to the mutations may cause malignant transformation, tumor spread and tumor resistance to therapy that induces DNA damage. ${ }^{2}$ The main function of protein 53 is for a cessation of cell cycle and initiation of apoptosis induced by DNA damage. ${ }^{3}$ The process of apoptosis is controlled by a balance between pro-apoptosis and anti-apoptosis genes. Among that genes control apoptosis which the most instrumental is BCL-2 gene that function to protect tumor cells from apoptosis process that allows the cells to keep growing. ${ }^{4}$ Breast cancer treatment using chemotherapeutic agents is still an option in the treatment of cancer. Chemotherapeutic agent commonly used in the treatment of breast cancer is Doxorubicin. ${ }^{5}$ The use of Doxorubicin chemotherapeutic agent becomes limited due to the problem of its toxic effects on normal tissues of the body and is also not selective. ${ }^{6}$

The potential approach in addressing the side effect of chemotherapy is by using co-chemotherapy agents. One of the agents potentially used in combination with chemotherapeutic agents is based on natural materials. ${ }^{7}$ A natural material that has potential as a co-chemotherapy agent is the root of Eurycoma longifolia Jack. E. longifolia Jack root has a bioactive compound that is quassinoid. The main content of the quassinoid is eurycomanone which has anti-cancer effects. ${ }^{8}$

Some in vitro studies have proved that ethanol extract of E. longifolia Jack root combined with Doxorubicin by in vitro may enhance the effects of Doxorubicin work to be more synergistic with the increasing expression of p53 triggers apoptosis process. ${ }^{9}$ Ethyl acetate fraction of ethanol extract of E. longifolia Jack root and Doxorubicin as co-chemotherapy in an in vitro manner has the activity to inhibit cell T47D through the mechanism of increasing expression of Bax and decreasing expression of Bcl-2. ${ }^{10}$ Ethanol extract of E. longifolia root in breast cancer of female Sprague-Dawley (SD) rats at a dose of $400 \mathrm{mg} / \mathrm{kgB} . \mathrm{W}$ were administered before and during induction of DMBA is able to decrease the expression of mutant $\mathrm{p} 53$ protein (pro-apoptosis) and inhibit the breast cancer growth in female Sprague-Dawley rats were induced by DMBA. ${ }^{11}$ Mutations or abnormalities of p53 gene lead to absenteeism activation of the Bax apoptotic gene. The occurrence of inactivation in the Bax caused the cells do not undergo apoptosis. Besides, changes in the inhibition function of BCL-2 apoptotic gene would lead to an increase in gene expression or overexpression of the gene, resulting in the cells to do not undergo apoptosis more and more. ${ }^{3}$ It needs to do research to find out that the co-chemotherapy ethyl acetate fraction of E. longifolia root can lower the expression of mutant p53 and Bcl-2.

\section{METHODS}

\section{Materials and tools}

The test materials used were Eurycoma longifolia Jack plant from Martapura, South Kalimantan, CMC-Na 0.5\%, corn oil (Superindo 365), 7.12 dimetilbenz(a)antrasen (DMBA) 20 mg/kgB.W (SIGMA-Aldrich), Doxorubicin (OGB Sanbe $2 \mathrm{mg} / \mathrm{ml}$ ), 70\% ethanol (Genera Labora), formaldehyde $10 \%$, and $\mathrm{NaCl}$ physiology. 
Experimental animals that used in this study were female Sprague Dawley (SD) rats with a body weight of 100-200 grams and 2 months old. ${ }^{12}$ The tools that used were magnetic stirrer (LABINCO), Jar, analytical balance (HWH), rotary evaporator (Heidolph), a set of surgical tools, oven (Binder), chamber (Larrag), water bath (Memmert), glass tools (Pyrex), an optilab which is connected to a computer (OLYMPUS DP12).

\section{Research Procedures}

This study is divided into two phases, that are the making ethyl acetate fraction of E. longifolia Jack and the test of carcinogenesis.

Making ethyl acetate fraction from $E$. longifolia Jack roots

Identification of E. longifolia Jack plant was conducted in the Laboratory of Biology, Faculty of Pharmacy, University of Ahmad Dahlan, Yogyakarta. Simplicia powders of E. longifolia Jack roots were weighed each about 100 grams and then separately extracted with $70 \%$ ethanol using maceration method. The ethanol extracts viscous diluted with hot water of $100 \mathrm{ml}$, stirring constantly, until dilute and homogeneous, then put in a separating funnel, fractionated by liquid-liquid extraction with ethyl acetate solvent. As much 50 grams of ethanol extract was fractionated using $20 \mathrm{~mL}$ ethyl acetate and was done by precipitating-and-pouring by 5 times. The fraction is then concentrated to obtain the soluble fraction and insoluble fraction in ethyl acetate.

\section{Co-chemotherapy test ethyl acetate fraction of E. longifolia Jack roots in an in vivo manner}

Rats were maintained in enough ventilated room, provided with food in the form of pellets and drink in the form of water sufficiently. The animals were adapted to the cage for 1 week prior to treatment. Animal trials have obtained ethics approval letter (Ethical Approval) of the Research Ethics Committee of the University of Ahmad Dahlan (UAD KEP) under number
011505 044. The carcinogen solution of DMBA (Sigma-Aldrich) diluted with corn oil. DMBA solution administered orally to the experimental animals with a dose of $20 \mathrm{mg} / \mathrm{kg}$ b.w. for 5 weeks with administration 2 times a week. DMBA solution always prepared immediately, before being given to the experimental animals. ${ }^{13}$ Ethyl acetate fraction of $\mathrm{E}$. longifolia roots according to the dose suspended in a solution of $0.5 \%$ CMC-Na. Solution of ethyl acetate fraction of $\mathrm{E}$. longifolia roots in $0,5 \% \mathrm{CMC}-\mathrm{Na}$ is always to be newly prepared prior to administration to the experimental animals. A single dose that used is $100 \mathrm{mg} / \mathrm{kg} \mathrm{BW.}{ }^{14}$

Female Sprague-Dawley rats aged 2 months were divided into 5 groups. Each group consisting of 7 female Sprague-Dawley rats. Group 1 (Normal), group 2 DMBA $20 \mathrm{mg} / \mathrm{kg}$ b.w., group 3 DMBA $20 \mathrm{mg} / \mathrm{kgB} . W+$ Doxorubicin $1.12 \mathrm{mg} / \mathrm{kg}$ b.w, group 4 DMBA $20 \mathrm{mg} / \mathrm{kg}$ b.w+Ethyl acetate fraction of E. longifolia root $100 \mathrm{mg} / \mathrm{kg} \mathrm{b.w}$, and group 5 DMBA $20 \mathrm{mg} / \mathrm{kg}$ b.w +Doxorubicin of $1.12 \mathrm{mg} / \mathrm{kg}+$ Ethyl acetate fraction of E. longifolia roots $100 \mathrm{mg} / \mathrm{kg}$ b.w Observation of tumors incidence conducted by palpation at week 6 of treatment. DMBA administration time and treatment with Doxorubicin as well as Ethyl Acetate Fraction of E. longifolia roots can be seen in Table I.

\section{Immunohistochemical staining and analysis}

This study used a mouse monoclonal antibody p53 mutant produced by BioGenex and Bcl-2 produced by Bioss. Procedures used for immunohistochemistry in this study was the procedure of Pathology of Anatomy Laboratory, Dr. Sardjito Generale Hospital.

The data obtained in this experiment is the number of cells expressed mutant p53 antibody and Bcl-2. Genes that expressed it were brown while those not expressed it were purple or blue and total cell number. Furthermore, based on the data it was computed in percent (\%) immunohistochemical expression that was 
Table 1. Timing of DMBA administration and treatment with Doxorubicin as well as Ethyl Acetate Fraction of E. longifolia root

\begin{tabular}{cllcl}
\hline Week & \multicolumn{1}{c}{ Fraction Treatment } & $\begin{array}{c}\text { Doxorubicin } \\
\text { Control }\end{array}$ & DMBA Control & Normal \\
\hline $1-5$ & & $\begin{array}{l}2 \times 1 \text { a week DMBA in } \\
\text { corn oil orally }\end{array}$ & Feed + aquadest \\
6-10 & $\begin{array}{l}\text { Every day it was administered } \\
\text { with ethyl acetate fraction of the } \\
\text { E. longifolia root }\end{array}$ & $\begin{array}{l}\text { Doxorubicin } \\
\text { intraperitoneally }\end{array}$ & Feed + aquadest \\
$10-16$ & $\begin{array}{l}\text { Every day it was administered } \\
\text { with ethyl acetate fraction of the } \\
\text { E. longifolia root }\end{array}$ & Feed + aquadest \\
\hline
\end{tabular}

calculated using the formula:

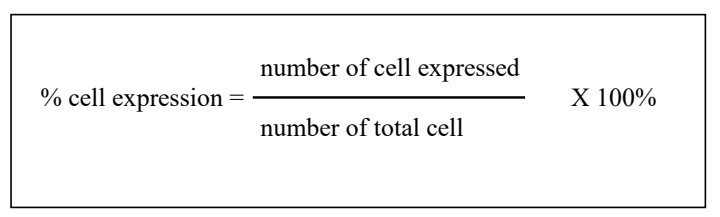

Percent expression of each group were statistically analyzed using SPSS 19 for windows. Statistical analysis of the results of mutant p53 and Bcl-2 immunohistochemistry value is done by using a nonparametric statistics KruskalWallis test followed by using the Mann-Whitney level of $95 \%$.

\section{RESULTS}

The extract obtained from $5 \mathrm{~kg}$ of dry powder of E. longifolia roots were extracted with $70 \%$ ethanol solution using maceration to produce ethanol extract of E. longifolia roots as much 121.36 grams with a yield of $2.92 \%$. Subsequently, the extract was fractionated using ethyl acetate. Selection of the ethyl acetate was be based on the differences of polarity with ethanol to reduce the compounds component were extracted in the ethyl acetate solution. ${ }^{15}$ Ethyl acetate fraction of Eurycoma longifolia Jack roots has been proven to have high cytotoxic activity against human breast cancer cell in line-MCF-7 and selective against cells of normal breast MCF- $10 \mathrm{~A} .{ }^{16} \mathrm{~A}$ total of $50 \mathrm{~g}$ of ethanol extract of E. longifolia roots was fractionated using $20 \mathrm{~mL}$ ethyl acetate and it was done through precipitating-and-pouring by 5 times.

The results of DMBA induction at a dose of 20 $\mathrm{mg} / \mathrm{kg}$ body weight by 10 times administration in observation for 16 weeks after the last administration of DMBA during palpation and nodules observations was not formed. It is likely due to the rats which used were old enough of 2 months. Appropriate age for the induction of mammary carcinogenesis is 1.5 months old due to it is an early puberty. ${ }^{12}$ Microscopically, based on histopathological analysis the DMBA-induced rats showed the presence of epithelial hyperplasia and they underwent adenocarcinoma. The rats also suffered from bleeding on the nose and nails. This is due to the toxic effects of DMBA and Doxorubicin is already noticeable. The bleeding is presumably related to the side effects of DMBA that effects on the increasing production of VEGF and the occur of angiogenesis. Angiogenesis is the formation of new blood vessels functioning to supply nutrients and oxygen to cancer cells so that it can develop continuously. ${ }^{17}$

Expression of mutant p53 protein and Bcl-2 was observed after 16 weeks of administration of treatment using a microscope with a magnification of $400 \mathrm{x}$ which complemented with optilab.

In the DMBA group when it is compared to the healthy group showed differences in its color. Cells Cells figure expresses the mutant p53 protein and Bcl-2 in breast tissue of rats shown in Figure 1. 

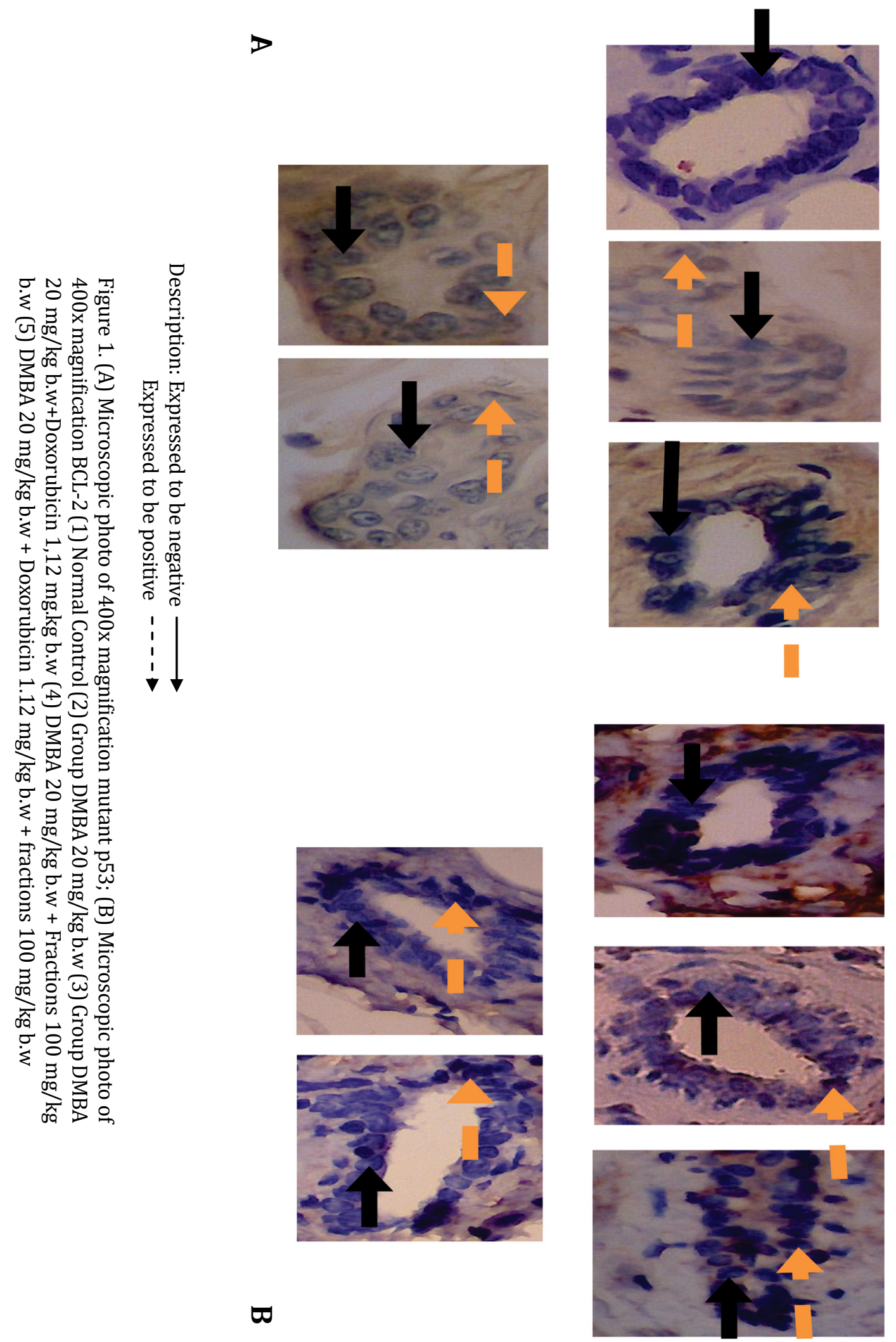
The cells express the mutant p53 protein will appear brown-colored in the cytoplasm of that cells and the cells express Bcl-2 protein would appear colored brown. ${ }^{14,18}$ Percentage analysis of the mutant $\mathrm{p} 53$ and $\mathrm{Bcl}-2$ expression was calculated by calculating the number of cells that expressed divided by the number of total cells multiplied by $100 \%$. The observation result of the percentage of mutant $\mathrm{p} 53$ protein and Bcl-2 expression after being treated can be seen in Table 2.

Table 2. Observation results on the percentage mean of mutant p53 protein and Bcl-2 expression after being treated with Doxorubicin and Ethyl Acetate Fraction of E. longifolia Roots in DMBA-Induced Rats

\begin{tabular}{lcc}
\hline \multicolumn{1}{c}{ Group } & $\begin{array}{c}\text { Percentage of expression of } \\
\text { mutant p53 } \mathbf{( \% )} \pm \mathbf{S D}\end{array}$ & $\begin{array}{c}\text { Percentage of expression of Bcl- } \\
\mathbf{2}(\mathbf{\%}) \pm \text { SD }\end{array}$ \\
\hline Normal & $9.35 \pm 0.32$ & $20,62 \pm 10,09$ \\
DMBA & $21.65 \pm 1.60$ & $52,83 \pm 3,61$ \\
DMBA + Doxo & $10.72 \pm 2.52$ & $24,38 \pm 3,54$ \\
DMBA + FAPB & $11.63 \pm 3.39$ & $38,01 \pm 6,25$ \\
DMBA + Doxo + FAPB & $12.72 \pm 3.44$ & $27,99 \pm 4,27$ \\
\hline
\end{tabular}

The significance value obtained in the Kruskal-Walis test was $0.000(\mathrm{p}<0.05)$, followed by Mann Whitney test, results can be seen on Table 3.

Table 3. Mann-Whitney test results of the expression levels of mutant p53 in normal group, DMBA $20 \mathrm{mg} /$ kg b.w, DMBA $20 \mathrm{mg} / \mathrm{kg}$ b.w + Doxorubicin 1:12 mg/kg b.w, DMBA $20 \mathrm{mg} / \mathrm{kg}$ b.w + Fraction $100 \mathrm{mg} / \mathrm{kg}$ b.w, DMBA $20 \mathrm{mg} / \mathrm{kg}$ b.w + Doxorubicin 1:12 mg/kg b.w + Fractions $100 \mathrm{mg} / \mathrm{kg}$ b.w

\begin{tabular}{|c|c|c|c|c|c|}
\hline & Group & $\begin{array}{l}\text { significance of } \\
\text { mutant p53 }\end{array}$ & $\begin{array}{l}\text { interpretation } \\
\text { of mutant p53 }\end{array}$ & $\begin{array}{l}\text { significance } \\
\text { of Bcl-2 }\end{array}$ & $\begin{array}{l}\text { interpretation } \\
\text { of Bcl-2 }\end{array}$ \\
\hline \multirow[t]{4}{*}{ Normal } & DMBA & 0,000 & $\begin{array}{l}\text { significant } \\
\text { difference }\end{array}$ & 0,000 & $\begin{array}{l}\text { significant } \\
\text { difference }\end{array}$ \\
\hline & DMBA + Doxo & 0,160 & not significant & 0,887 & not significant \\
\hline & DMBA + Frac & 0,378 & not significant & 0,000 & $\begin{array}{l}\text { significant } \\
\text { difference }\end{array}$ \\
\hline & DMBA + Doxo+Frac & 0,007 & $\begin{array}{l}\text { significant } \\
\text { difference }\end{array}$ & 0,128 & not significant \\
\hline \multirow[t]{3}{*}{ DMBA } & DMBA + Doxo & 0,000 & $\begin{array}{l}\text { significant } \\
\text { difference }\end{array}$ & 0,000 & $\begin{array}{l}\text { significant } \\
\text { difference }\end{array}$ \\
\hline & DMBA + Frac & 0,000 & $\begin{array}{l}\text { significant } \\
\text { difference }\end{array}$ & 0,000 & $\begin{array}{l}\text { significant } \\
\text { difference }\end{array}$ \\
\hline & DMBA + Doxo+Frac & 0,000 & $\begin{array}{l}\text { significant } \\
\text { difference }\end{array}$ & 0,000 & $\begin{array}{l}\text { significant } \\
\text { difference }\end{array}$ \\
\hline \multirow[t]{2}{*}{ DMBA + Doxo } & DMBA + Frac & 1,000 & not significant & 0,000 & $\begin{array}{l}\text { significant } \\
\text { difference }\end{array}$ \\
\hline & DMBA + Doxo + Frac & 0,242 & not significant & 0,520 & not significant \\
\hline DMBA + Frac & DMBA + Doxo + Frac & 0,198 & not significant & 0,000 & $\begin{array}{l}\text { significant } \\
\text { difference }\end{array}$ \\
\hline
\end{tabular}




\section{DISCUSSION}

Protein 53 has a crucial role in controlling the cell cycle, apoptosis and maintaining genomic stability. Loss of p53 function as a result of mutations may cause malignant transformation, tumor spread and tumor resistance to therapy that induces DNA damage. Mutations of p53 will produce an abnormal protein with very long half-life, caused the accumulation of these products, whose its expression can be detected by immunohistochemistry. ${ }^{2}$ Most of the mutation of genes is missense mutation causing amino acid substitutions in the wild-type protein. A missense mutation causes a change in one amino acid and the type of this point mutation in the DNA-binding domain of p53 (exons 5 to 8) can coded proteins transcriptionally inactive or show aberrant transcriptional activity compared to normal or wild-type p53. Although the normal cells also generally have lower levels of protein 53 as a result of the half-life is shorter than wild-type proteins, missense mutation of p53 often encodes a protein product that resistant to degradation, and as a result, mutant $\mathrm{p} 53$ protein accumulates in the nucleus. This gene mutation causes the loss of function of the gene and it is the basis of changes in the occurrence of cancer. The main function of the protein p53 is to terminate cell cycle and initiate apoptosis triggered by DNA damage. The process of apoptosis is controlled by a balance between pro-apoptosis and antiapoptosis genes. Among the genes that control apoptosis which the most instrumental is BCL-2 genes that protect tumor cells from apoptosis.

Figure 1 Results of research on groups of DMBA when compared to the normal group showed a difference of color. This indicates that the DMBA-induced test animals expressing mutant p53 for DMBA reactive metabolites to form DNA adducts and cause mutations mutation occurs in the gene p53 in mammary. ${ }^{19,20}$ p53 mutations can lead to increased expression of Bcl-2. ${ }^{21}$

The percentage of mutant $\mathrm{p} 53$ expression and Bcl-2 in the DMBA group than the healthy group indicate a percentage value that is greater than the normal group as shown in Table II and there is a significant differences between the normal group and the group DMBA $20 \mathrm{mg} / \mathrm{kg}$ b.w as shown in Table III, in the expression of mutant p53 and Bcl-2 is shown with a significance value of $0.000(\mathrm{p}<0.05)$. DMBA group of $20 \mathrm{mg} / \mathrm{kg}$ b.w of mutant $p 53$ expression discount percent higher compared with the normal group in the amount of $21.65 \pm 1.60$ and for the normal group amounted to $9.35 \pm 0.32$. This shows that the reactive metabolites of DMBA will cause damage to DNA. ${ }^{13}$ Damage to DNA can cause mutations in the p53 gene, p53 inactivation can lead to increased expression of Bcl-2. In the group of doxorubicin administration decreased the percentage of expression of mutant p53 and Bcl-2. It is proved that doxorubicin can decrease the expression of Bcl-2 with path induces the release of cytochrome $c$ from mitochondria to the cytoplasm, activation of Caspase 9 and may induce apoptosis ${ }^{22}$ and can reduce the expression of mutant $\mathrm{p} 53 .{ }^{23}$ However Doxorubicin cause side effects such as changes in the use of cardiovascular, ${ }^{24 ; 25}$ hepatotoxicity, ${ }^{26}$ as well as their toxic effects on normal tissues of the body. ${ }^{27}$ Furthermore, administration of co-chemotherapy ethyl acetate fraction of E. longifolia roots was observed for the purpose of reducing the side effects of Doxorubicin and improving the effectiveness of chemotherapy.

In the co-chemotherapy group ethyl acetate fraction $100 \mathrm{mg} / \mathrm{kg}$ + Doxorubicin $1.12 \mathrm{mg} / \mathrm{kg}$ shown to result in a significant difference with a significance value compared with DMBA 20 $\mathrm{mg} / \mathrm{kg}+$ co-chemotherapy ethyl acetate fraction $100 \mathrm{mg} / \mathrm{kg}+$ Doxorubicin $1.12 \mathrm{mg} / \mathrm{kg}$ was $0.198(\mathrm{p}<0.05)$. The percentage decrease in the expression of mutant $\mathrm{p} 53$ with co-administration of chemotherapy is not better with the provision of ethyl acetate fraction only. This is due to the low dose of ethyl acetate fraction used in cochemotherapy, so the need to increase the dose of ethyl acetate fraction in order to maximize the effect of co-kemoetrapi in reducing the expression of mutant p53. Decreased expression of mutant p53 can induce the release of cytochrome $\mathrm{c}$ from mitochondria to the cytoplasm, activation of caspase 9 further activates another caspase such 
as caspase 3 and 7, and caspase 3 will initiate apoptosis. ${ }^{28}$

Effectiveness of chemotherapy can be seen by comparing groups of DMBA $20 \mathrm{mg} / \mathrm{kg}$ doxorubicin $+1.12 \mathrm{mg} / \mathrm{kg}$ to groups of DMBA $20 \mathrm{mg} / \mathrm{kg}+$ co-chemotherapy ethyl acetate fraction $100 \mathrm{mg} / \mathrm{kg}+$ Doxorubicin 1, $12 \mathrm{mg} /$ $\mathrm{kg}$. Statistical analysis showed a significant difference with a significance value of 0.128 $(p<0.05)$. However, the percentage decrease in the expression of Bcl-2 co-chemotherapy group was no better than the group with the administration of doxorubicin alone. It is caused by a combination of doxorubicin dose and ethyl acetate fraction is still not quite right, so that the decreased expression of $\mathrm{Bcl}-2$ is better than the use of single doxorubicin. However, the use of co-chemotherapy still had an advantage compared to the use of single doxorubicin because doxorubicin has a lot of side effects on chronic usage that is irreversible, including the formation of congestive heart failure and can cause cardiotoxicity. ${ }^{29}$ Doxorubicin is also capable of causing a fragmentation or normal cell DNA damage and subsequent effect on normal cell replication process. The ethyl acetate fraction does not cause damage to the heart's normal cells. ${ }^{11}$ Thus the use of co-chemotherapy can reduce the side effects of doxorubicin and can trigger apoptosis with decreased expression of Bcl-2 and acts as an anti-cancer agent cytoselective for eurycomanone relatively nontoxic to normal cells.

The use of co-chemotherapy ethyl acetate fraction roots of the earth peg and Doxorubicin in this study were able to decrease the expression of mutant $\mathrm{p} 53$ and $\mathrm{Bcl}-2$ that will happen activation Puma and Noxa. Both of these proteins activate the multidomain protein Bax or Bak. Activation of Bax and Bak by Puma and Noxa regulated by the anti-apoptotic protein Bcl-2, Bcl-xL, MCL1. On the condition of mutant p53 decreased, the expression of Bcl-2 also will decrease and an increase in the expression of Bax. Bax activation causes the release of cytochrome c to cytochrome c will form a complex with Apaf-1 and formed trimer Apaf-1/ cytochrome c/ procaspase 9 called apoptosom. Apoptosom formed to induce activation of procaspase 9 into caspase 9 . Specific Aspartyl Cysteine Protease-9 (Caspase 9) further activates another caspase such as caspase 3 and 7 , causing the cell to undergo apoptosis. ${ }^{13}$ This fraction can be further developed as a co-agent chemotherapy.

\section{CONCLUSIONS}

The conclusion of this study is that administrating co-chemotherapy of ethyl acetate fraction of the E. longifolia Jack roots and doxorubicin was able to induce apoptosis of breast cancer cells through the reduction of mutant p53 and Bcl-2.

\section{ACKNOWLEDGEMENT}

A great thank to the DIKTI (Directorate General of Higher Education) through its funding program to the post-graduate team and LPP UAD (Center for Research and Development Ahmad Dahlan University) for the grants provide for this study.

\section{REFERENCES}

1. Lestari DY, Joewarini E. Ekspresi p53 Mutant dan EGFR pada Benign, Borderline, dan Malignant Phyllodes Tumor. Majalah Patologi. 2015;24(2):33-8.

2. Choudhury M, Goyal S, Pujani M, Pujani M. A cytohistological study of p53 overexpression in ovarian neoplasms. South Asian Journal of Cancer. 2012;1(2):59-62.

3. Sinha S, Malonia SK, Mittal SPK, Singh K, Kadreppa S, Kamat R, et al. Coordinated regulation of p53 apoptotic targets BAX and PUMA by SMAR1 through an identical MAR element. The EMBO Journal. 2010;29(4):830-42.

4. Raspollini MR, Amunni G, Villanucci A, Castiglione F, Deglinnocenti DR, Baroni G, et al. HER-2/neu and bcl-2 in Ovarian Carcinoma. Applied Immunohistochemistry \& Molecular Morphology. 2006;14(2):181-6.

5. Jenie RI, Meiyanto E. Aplikasi Ko-kemoterapi fraksi etil Asetat ekstrak etanolik Daun Sambung Nyawa (Gynura Procumbens (Lour.) Merr.) pada sel kanker payuda- 
ra MCF-7. Majalah Ilmu Kefarmasian. 2009;132-41.

6. Riris I, Edy M. Ko-kemoterapi ekstrak Etanolik Daun Sambung (Gynura procumbens (Lour.) Merr.) dan Doxorubicin pada sel kanker payudara. Majalah Farmasi Indonesia. 2007;8(2):81-7.

7. Tyagi AK, Agarwal C, Chan DCF, Agarwal R. Synergistic anti-cancer effects of silibinin with conventional cytotoxic agents doxorubicin, cisplatin and carboplatin against human breast carcinoma MCF-7 and MDA-MB468 cells. Oncology reports. 2004;(2):493-9.

8. Mahfudh N, Pihie AHL. Eurycomanone induces apoptosis through the up-regulation of p53 in Human Cervical Carcinoma cells. Journal of Cancer Molecules. 2008;4(4):109-15.

9. Niah R. Efek ekstrak etanol akar Pasak Bumi (Eurycoma longifolia. Jack) terhadap ekspresi p53 pada organ hati tikus Galur Sprague Dawler yang diberikan Doxorubicin. Ahmad Dahlan University. Yogyakarta; 2013.

10. Ahidin D. Efek Ko-kemoterapi Fraksi Etil Asetat Ekstrak Etanol Akar Pasak Bumi (Eurycoma longifolia Jack) dan Doxorubicin terhadap Ekspresi BAX dan BCL-2 Pada Sel T47D. Program Pasca Sarjana Farmasi, Universitas Ahmad Dahlan; 2015.

11. Normakiyah, Nurani LH. Pengaruh pemberian ekstrak etanol akar Pasak Bumi (Eurycoma longifolia Jack) terhadap ekspresi Protein p53 pada kanker payudara tikus betina Sprague Dawley (SD) yang diinduksi 7,12-Dimetilbenz( $\alpha$ )antrasen (DMBA). Pharmacon Journal of Indonesian Pharmacy. Muhammadiyah Surakarta University. Surakarta; 2010.

12. Kubatka P, Ahlersová E, Ahlers I, Bojková B, Kalická K, Adámeková E, et al. Variability of mammary carcinogenesis induction in female Sprague-Dawley and Wistar:Han rats: The effect of season and age. Physiological research. 2002;51(6):633-40.

13. Meiyanto E, Susilowati S, Tasminatun S, Murwanti R, Sugiyanto. Efek kemopreventif ekstrak etanolik Gynura procumbens
(Lour), Merr pada karsinogenesis kanker payudara tikus. Majalah Farmasi Indonesia. 2007;18(3):154 - 61.

14. Nurani LH, Utami D, Salamah N. The cytotoxic effect of isolate of Eurycomanone of Pasak Bumi (Eurycoma longifolia Jack) Roots to T47D cell lines. In: Proceeding International Joint Symposium Faculty of Medicines. Yogyakarta: Gadjah Mada University; 2011.

15. Edawati Z. Uji aktivitas antioksidan ekstrak Metanol Ascidia Didemnum sp. dari Kepulauan Seribu dengan metode 1,1Difenil2Pikrilhidrazil (DPPH) dan identifikasi golongan senyawa dari fraksi teraktif. FMIPA UI. Depok; 2012.

16. Tee TT, Azimahtol HLP. Induction of apoptosis by Eurycoma longifolia jack extracts. Anticancer research. 2005;25(3B):220514.

17. Tammana T. Angiogenesis dan metastasis. Bandung: Faculty of Dentistry. Padjadjaran University; 2012.

18. Meiyanto E, Jenie IR, Ashari AR, Febriansah R, Asyhar A, Sukamdi PD. Peningkatan ekspresi p53 oleh ekstrak Etanolik Rumput Mutiara (Hedyotis corymbosa) pada sel hepar tikus Sprague Dawley terinduksi 7,12-Dimetilbenz(a)Antrasena. Jurnal Farmasi Indonesia. 2010;11.

19. Weimer T L, Reddy AP, Harttig U, Alexander D, Stamm SC, Miller MR, et al. Influence of beta-naphthoflavone on 7,12-dimethylbenz(a)anthracene metabolism, DNA adduction, and tumorigenicity in rainbow trout. Toxicological sciences. 2000;57(2):217-28.

20. Pratiniyata, Roosdiana S, Oktavianie A. Pengaruh Induksi DMBA (7,12-dimethylbenz $(\alpha)$ anthracene) Multiple Low Dose (MLD) terhadap kadar estrogen pada serum darah tikus (Rattus norvegicus). Program Studi Kedokteran Hewan. Universitas Brawijaya. Malang; 2012.

21. Arun B, Kilic G, Yen C, Foster B, Yardley $\mathrm{D}$, Gaynor R, et al. Correlation of bcl-2 and p53 expression in primary breast tumors and corresponding metastatic lymph nodes. America Cancer Sosiety. 
2003;98(12):2554-9.

22. Sharifi S, Barar J, Hejazi MS, Samadi, N. Doxorubicin changes Bax/Bcl-XL Ratio, caspase- 8 and 9 in Breast Cancer Cells. Advanced Pharmaceutical Bulletin. 2015;5(3):351-9.

23. Wicaksono AS. Pengaruh Pemberian Senyawa Turunan Isoflavon 1,2-epoksi-3-[33(3,4-dimetoksifenil)-4h-1-benzopiran-4on] Propane terhadap Ekspresi p53 pada Model Kanker Payudara Tikus Spraque Dawley yang Diinduksi DMBA. Gadjah Mada University. Yogyakarta; 2015.

24. Distefano G. Molecular pathogenetic mechanisms and new therapeutic perspectives in anthracycline-induced cardiomyopathy. Italian Journal of Pediatrics. 2009;35(1):37.

25. Benjamin RS, Ewer MS. Doxorubicin cardiotoxicity: Clinical aspect, recognition, monitoring, treatment, and prevention. In: Yeh E, Ewer MS, editors. Cancer and the heart. Ontario: BC Decker; 2006. p. 9-31.

26. Chen J, Zhang B, Wong N, To AW, Lo KF, Chan AW, et al. Sirtuin 1 is upregulated in a subset of hepatocellular carcinomas where it is essential for telomere maintenance and tumor cell growth. Cancer Research. 2011;71(12):4138-49.

27. Fimognari $C$, Nusse MN, Lenzi M, Sciuscio D, Cantelli-Forti G, Hrelia P. Sulforaphane increases the efficacy of doxorubicin in mouse fibroblasts characterized by p53 mutations. Mutation Research. 2006;601(1-2):92-101.

28. Reuter S, Eifes S, Dicato M, Aggarwal BB, Diederich M. Modulation of anti-apoptotic and survival pathways by curcumin as strategy to induce apoptosis in cancer cells. Biochem Pharmacol. 2008;76(11):134051.

29. Zhao L, Wientjes MG, Au JLS. Evaluation of combination chemotherapy: Integration of nonlinear regression, curve shift, isobologram, and combination index analyses. Clinical Cancer Research. 2004;10(23):7994-8004. 